\title{
THE PETROLOGY OF THE CLEVE KIMBERLITE, EYRE PENINSULA, SOUTH AUSTRALIA.
}

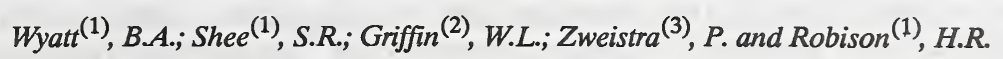

(1) Stockdale Prospecting Ltd., 60 Wilson Street South Yarra Vic 3141 Australia; (2) CSIRO, Div. Exploration Geoscience, PO Box 136, North Ryde NSW 2113 Australia; (3) Anglo American Res. Labs., PO Box 106, Crown Mines, 2025 South Africa.

\section{INTRODUCTION}

The Jurassic Cleve-01 kimberlite is situated some $10 \mathrm{kms}$ north of the town of Cleve on the Eyre Peninsula. It occurs as a small dyke and blow complex, having a width of $20 \mathrm{~m}$ and strike length of a few hundred metres, and has been dated at $180 \pm 3 \mathrm{Ma}$ on $\mathrm{U}-\mathrm{Pb}$ in groundmass perovskite (Bristow, unpublished data).

The Eyre Peninsula forms part of the Archaen Gawler Craton which has undergone 3 cycles of protracted orogenic development during the early to mid-Proterozoic, but has essentially remained stable since ca.1450 Ma (see Fanning et. al. 1988). Cleve-01 intrudes the Mangalo schists of the Proterozoic Hutchison formation. To the west, a thick sequence of younger Palaeozoic and Mesozoic sediments occur in the nearby Polda Trough, an intra cratonic half graben with which the emplacement of cleve-01 may be associated.

\section{Petrography}

The petrographic terminology used in this paper is based on Skinner and Clement, (1979). Cleve-01 consists of both diatreme and hypabyssal facies kimberlite suggesting derivation from the lower levels of a diatreme. Mineralogically it can be described as an opaque-bearing phlogopitemonticellite kimberlite of Group 1 type (Smith, 1983). Three varieties of kimberlite are present; porphyritic, porphyritic breccia and pelletaltuffisitic kimberlite.

The porphyritic variety contains abundant euhedral, serpentinised olivine phenocrysts (mean $=0.5 \mathrm{~mm}$, up to $1.2 \mathrm{~mm}$ in size), scarce ilmenite microcrysts $(0.3$ to $0.6 \mathrm{~mm}$ in size) and occasional baked country rock xenoliths (up to $6 \mathrm{~mm}$ in length) set in a matrix consisting of granular serpentinised monticellite $(0.025$ to $0.060 \mathrm{~mm}$, mean $=0.04 \mathrm{~mm})$ and lesser phlogopite. Extremely rare, rounded macrocrystic grains of serpentinised olivine up to $4 \mathrm{~mm}$ are also present. The phlogopite occurs as small 10.01 to $0.02 \mathrm{~mm}$ ) laths and platelets interstitial to the monticellite. Possible melilite is also present. Scarce, small (0.5 mm) irregular segregations of calcite and serpentine occur in the matrix. Coarse $(0.025$ to $0.08 \mathrm{~mm})$ groundmass spinel and perovskite are abundant (10\%) and occur as subhedral to euhedral grains or in clusters up to $0.25 \mathrm{~mm}$ across. Subhedral to euhedral pyrite up to $0.02 \mathrm{~mm}$ is also fairly common. Rare groundmass ilmenite up to $0.03 \mathrm{~mm}$ is also present. Texturally, this variety is classified as a hypabyssal facies, weakly segregationary and porphyritic kimberlite. Mineralogically, it is an opaque-bearing phlogopitemonticellite kimberlite.

In some instances country rock xenoliths exceed 15 volume per cent. In such cases, the rock is classified texturally, as a hypabyssal facies, porphyritic breccia and, mineralogically as a richterite and opaque-bearing phlogopite-diopside-monticellite kimberlite. Petrographic relationships clearly indicate that the richterite and diopside have formed by reaction between the country rock xenoliths and the kimberlite magma. 
The pelletal-tuffisitic kimberlite consists of irregular to rounded pelletal lapilli and country rock fragments of biotite-quartz-feldspar gneiss up to $10 \mathrm{~mm}$ in size, set in a serpentinised matrix. The lapilli average $0.6 \mathrm{~mm}$ across with a few reaching $2 \mathrm{~mm}$ in diameter. The lapilli are cored by subhedral to euhedral olivine phenocrysts (no macrocrysts were observed) up to $1.3 \mathrm{~mm}$ in size and fragments (usually plagioclase or lesser quartz) of country rock xenoliths. The matrix of the lapilli consist of euhedral olivine microphenocrysts, euhedral and atoll textured spinels up to $0.1 \mathrm{~mm}$, subhedral perovskite, subhedral to euhedral pyrite $(0.015 \mathrm{~mm})$, granular serpentine probably after monticellite, fine phlogopite, secondary clays and fine diopside microlites. The diopside occurs mainly toward the outer margins of the lapilli matrix. The interpelletal matrix consists predominantly of fine grained serpentine, abundant diopside microlites and rare phlogopite. This variety is classified texturally as a diatreme facies pelletal-tuffisitic kimberlite. Mineralogically, it is an altered (clay mineralised), phlogopite-monticellite kimberlite.

\section{Mineral Chemistry of Concentrate Minerals.}

Cleve-01 is dominated by macrocrysts of ilmenite with lesser amounts of chromian spinels, garnets and rare clinopyroxene. The size distribution of the ilmenites are very strongly biased towards the finer $0.3-0.5 \mathrm{~mm}$

fractions compared to the coarser $1.0-2.0 \mathrm{~mm}$ fractions, with the compositions varying distinctly with size (Figure 1). MgO varies from a mode of $8 \mathrm{wt} \%$ in the coarse fraction to 11 wto in the fine fraction. $\mathrm{Cr}_{2} \mathrm{O}_{3}$ and $\mathrm{Al}_{2} \mathrm{O}_{3}$ is mostly less than 0.3 wt for all fractions. Proton probe. trace element data for ilmenites show a reasonably well defined positive $\mathrm{Nb}-2 \mathrm{r}$ relationship (ca $800-2000 \mathrm{ppm} \mathrm{Nb}, 400-800 \mathrm{ppm} \mathrm{Zr}$ ) but poorly defined $\mathrm{Nb}-\mathrm{Ni}$ (ca 0-700 ppm $\mathrm{Ni}$ ) and $\mathrm{Ni}-\mathrm{Mg}$ relationships when compared to the well constrained megacrystic suite from Monastery (Moore et al, in press).

The Cleve-01 ilmenites therefore probably derive from sampling of multibatch magmas, of which at least the fine high-Mg0 fraction may correspond to coarse grained microphenocrysts crystallising as an early groundmass phase. in the kimberlite magma.

The majority of the chromian spinels have 55-65 wt: $\mathrm{Cr}_{2} \mathrm{O}_{3}$ and less than 1 wt? $\mathrm{TiO}_{2}$. Two populations are defined by Mg0 contents; 8-12 wtr and 13-15 wtr respectively. A significant minority of grains have $\mathrm{TiO}_{2}$ 1-6 wtz, some of which may derive from coarse groundmass spinels. The trace element contents of the spinels are more or less in keeping with Group 1 kimberlites with respect to $\mathrm{Zn}(400-700 \mathrm{ppm})$ and $\mathrm{Ga}(10-60 \mathrm{ppm})$, but are high in Ni (1000 ppm compared to 600-700 ppm for other Group 1 kimberlites. They therefore do not have any obvious association with spinels from harzburgites or lherzolites (Griffin et al, this vol.). The high Ni may suggest a high temperature origin.

The Cleve-01 garnets are distinctly bi-modal, with low and high $\mathrm{Cr}_{2} \mathrm{O}_{3}$ populations being present $\left(1-3 \mathrm{wt}\right.$ and 5-9 wtr $\left.\mathrm{Cr}_{2} \mathrm{O}_{3}\right)$, and the vast majority belonging to the lherzolitic paragenesis (Sobolev, et al. 1973). virtually all the garnets are low $\mathrm{TiO}_{2}$ varieties (less than 0.4 wt $\mathrm{TiO}_{2}$ ), and typical high $\mathrm{TiO}_{2}$ megacrystic garnets are not present. Using the $\mathrm{Ni}$ garnet geothermometer (Griffin et al, 1989) essentially two temperature populations are defined; one at $\mathrm{Ca} 650-800^{\circ} \mathrm{C}(\mathrm{Y} / \mathrm{Ga}>2)$ and the other, $1000^{\circ}-1250^{\circ} \mathrm{C}(\mathrm{Y} / \mathrm{Ca}<1)$ corresponding to the low and high $\mathrm{Cr}_{2} \mathrm{O}_{3}$ groups respectively (Figure 2). Although the high temperature garnets fall into the diamond stability field assuming a normal continental geotherm, the very low $Y / G a$ ratios are atypical of most African and Siberian kimberlites (Griffin and Ryan, unpublished data). This population in fact may be related to a separate high- $\mathrm{Cr}_{2} \mathrm{O}_{3}$ suite formed at relatively low pressures as defined by the low temperature garnet population. 


\section{Conclusions}

Petrographic features such as the relative lack of coarse olivine xenocrysts, the coarse grain size of the matrix perovskites and spinels and the possible presence of melilite can be used as arguments favouring a fractionated kimberlite. This idea is supported by the presence of what are likely coarse groundmass ilmenites and high- $\mathrm{TiO}_{2}$ spinels. All concentrate minerals display distinctive multimodal populations. Viewed together with the high and low temperature garnet groups, these data suggest a complex petrogenetic and sampling history for cleve-01 which is related to a kimberlite undergoing fractionation during relatively slow and/or episodic emplacement. Such intrusive characteristics may account for the barren nature of the kimberlite in spite of the fact that it may have originated within the diamond stability field.

\section{References}

Fanning, C.M., Flint, R.B., Parker, A.J., Ludwig, K.R., and Blissett, A.H. (1988) Precamb. Res. 40/41, 363-386.

Griffin, W.L., Cousens, D.R., Ryan, C.G., Sie, S.H., and Suter, G.F. (1989). Contr. Min. Pet. 103, 199-202.

Griffin, w.L., Ryan, C.G., Gurney, J.J., Sobolev, N.v., and Win, T.T. (this vol.)

Moore, P.O., Griffin, W.L., Gurney, J.J., Ryan, C.G.,Cousens, D.R., Sie, S.H., and Suter, G.F., (in press) Contr. Min. Pet.

Skinner, E.M.W., and Clement, C.R. (1979). In Boyd, F.R. and Meyer, H.O.A. (Eds.) Kimberlites, diatremes and diamonds. A.G.U. Washington. 129-139.

Smith, C. (1983). Nature 304, 52-54.

Sobolev, N.V., Lavrentiev Yu G., Pokhilenko, N.P.. and Usova, L.V. (1973). Contr. Min. Pet., 40, 39-52
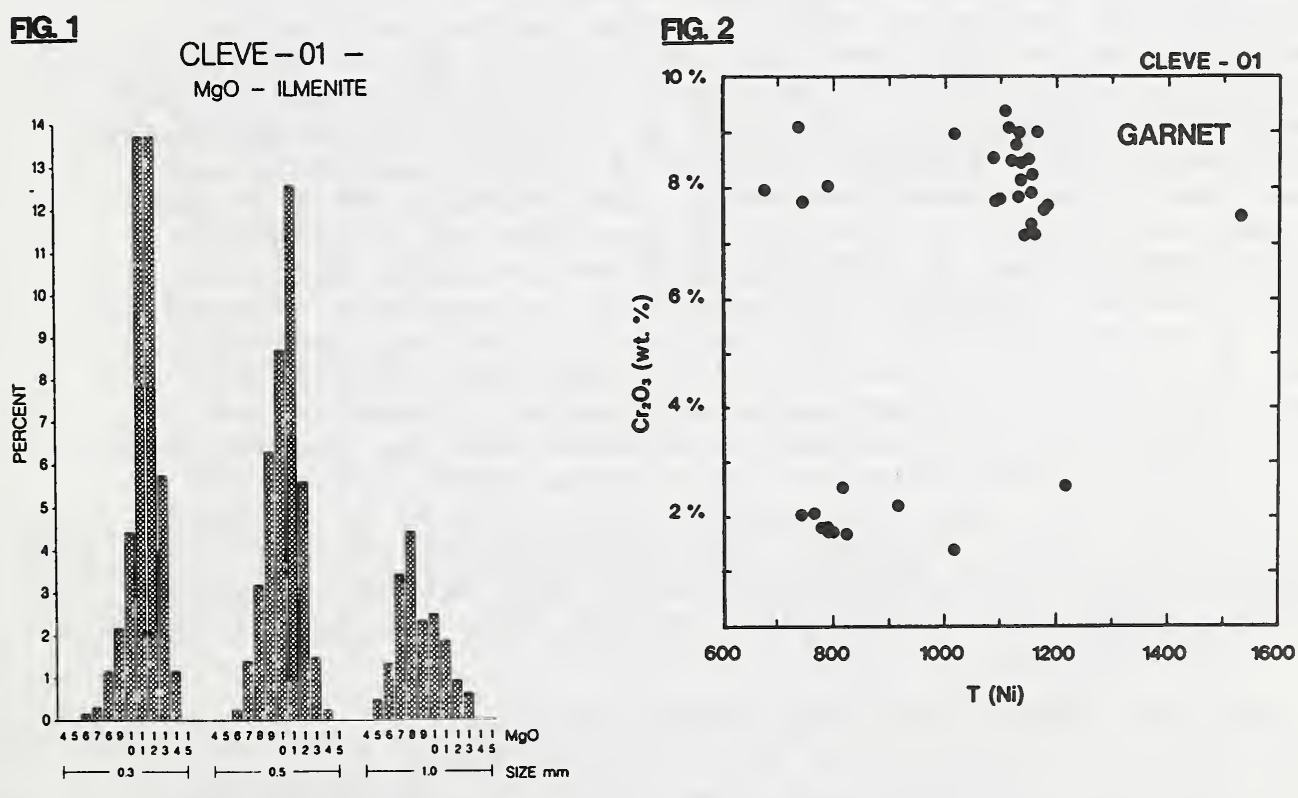

Fig. 1 Variation of MgO (wt $)$ ) as a function of size in cleve-01 ilmenites (1209 analysis).

Fig.2 Inferred $\mathrm{Ni}$ temp $\left({ }^{\circ} \mathrm{c}\right)$ distribution garnets from Cleve-01 as a function of $\mathrm{Cr}_{2} \mathrm{O}_{3}$. (see Griffin et at, 1989). 